\title{
GREEN \& SUSTAINABLE LUXURY: A STRATEGIC EVIDENCE
}

\author{
Corine Cohen, International University of Monaco, Monaco
}

\begin{abstract}
The purpose of this paper is to demonstrate the evident link between sustainability and luxury while explaining and illustrating the green and sustainable strategy of luxury companies. First, the luxury industry, its key figures and players will be presented. Many luxury groups \& firms are investing in exploring greener and more sustainable options, especially to answer their customers' expectations. An overview of what is happening across a number of different luxury product categories will allow understanding this eco-wave. Examples will be given in several luxury sectors: home design, automotive, haute-couture \& fashion, hospitality, yachting, jewelry.
\end{abstract}

The global luxury market represents 200 billion Euros (Bain \& Company, 2012). Despite the international economic crisis, it is a booming industry with an impressive growth, driven by the new rich of developing nations such as China and India. Moët Hennessy . Louis Vuitton, created in 1987 only, is the indisputable world leader with a revenue of 23.659 million Euros, an exclusive portfolio of 60 esteemed brands, a retail network of 3000 stores and almost 100000 employees, in 2011. Far behind, there are the Richemont Group, with its emblematic Cartier brand, and the luxury pole of PPR Group, so well represented by the Gucci Group. Beside these big players, many luxury houses have key roles in this highly competitive industry.

The heavy green and sustainable global trend, which is not so new (Henion \& Kinnear, 1976), is also present in the luxury industry. Durability, timeliness, craftsmanship, quality, authenticity, know how, are key words for defining luxury. The link with sustainability is thus obvious. Nevertheless, luxury companies have relatively recently accelerated the implementation of their sustainable strategy. The 2007 WWF report, which mentioned the poor grades of luxury firms in sustainability and social responsibility, has maybe accelerated the movement (Bendell \& Kleanthous, 2007).

But why is going green such an evidence for luxury companies? First, it is an absolute necessity: companies have limited natural resources to satisfy unlimited wants (Polonsky, 1994). They have to be effective in terms of resource management, which is source of cost saving and profitability. Second, the green luxury consumer is very aware of environmental issues. He is also very demanding and sensitive to the social condition of the extraction and exploitation of resources, meaning to corporate social responsibility. He has the "money power" and is ready to pay premium prices for a more sustainable product. In Asia, in particular, where Taoism and Buddhism represent a long tradition, green consumerism is a powerful movement (Sempels, 2012). It is a global phenomenon. Third, both the governments' and competition's pressures are becoming stronger. At last, with new tools of communication, a green and sustainable strategy has a clear impact on brand reputation.

Choosing a green and sustainable strategy is then a major decision. The management has to evaluate the importance of the green market in one hand, and its ability to differentiate its green offering on the other hand (Ginsberg, 2004). And the possibilities go from a "quiet" green strategy" to an extreme green strategy.

Green and sustainable luxury products or actions are launched every day. Let's just evoke some examples. In home design, the "Green Luxury Home" costs over 100 million dollars, is equipped with sustainable strategy and technology, is part of an eco-friendly rehabilitation project, uses geothermal heating and other renewable power production strategies, and produce more energy than it consumes. The "Kokopo House" uses rain water filtration for kitchen and bathroom, natural ventilation, solar power generation for low-power on-site LEDs, has a green design, and a luxury living. "Acqua Liana", uses the latest technologies in sustainability and costs $\$ 29,000,000$. In the eco-friendly luxury yachting sector, "Soliloquy" is the "supergreen super yacht". There are also many examples of green luxury hotels \& resorts. Environmentally Friendly Luxury Cars includes famous products and brands like "Lexus RX 400", "BMW plug-in hybrid car", and the "Ferrari Hy-Kers" model. Jaguar Land Rover has also a visible sustainable development policy. In luxury green fashion and accessories, the "HermesPetit $\mathrm{H}$ collection" is an interesting example. It is a collection of "unidentified poetic objects" made from factory scraps and defective materials. The green \& sustainable jewelry sector is very active with key actions and players like the Kimberley Process, Corporacion Oro Verde, the Alliance for Responsible Mining, The Responsible Jewelry Council.

In conclusion, luxury \& sustainable development is evidence. The power of the luxury consumers is determinant. The eco and social role of luxury companies is huge, and will have an impact on all industries.

References available upon request

Proceedings of AMS' World Marketing Congress Cultural Perspectives in Marketing (C 2012 